\title{
When the citation reflects the significance
}

\author{
Manh-Toan Ho, Huyen Thanh T. Nguyen \\ SDAG Lab, Centre for Interdisciplinary Social Research \\ Phenikaa University
}

Ha Dong district, Hanoi 100803, Vietnam

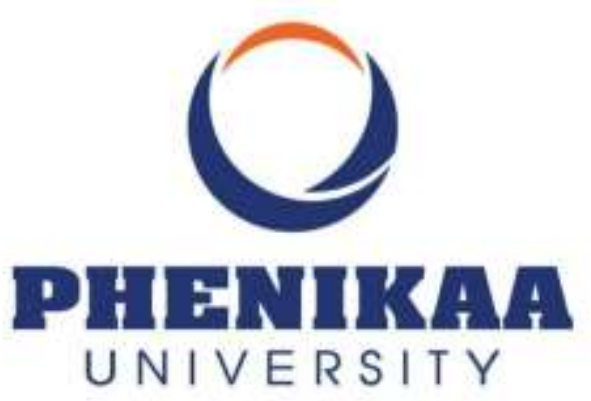

May 31, 2021

Our system checks research statistics several times a week for various reasons, including administrative and tactical planning [1]. The task is an obligation, not an option.

One of the statistics we frequently track is the number (and patterns) of citations that key works from our SDAG/ISR Center receive. This measure exists for numerous reasons that researchers today take for granted [2-3].

Today we stumbled on a newly published dissertation titled Meanings of Mindfulness and Spiritual Awakening: Affliction and Holistic Healing in Contemporary Cairo [4]. The work has been submitted for the degree of MA in Sociology-Anthropology from the American University in Cairo, School of Humanities and Social Sciences.

It is an interesting and intriguing research study, roughly 180 pages long. Its value is also stated explicitly in the abstract:

In this research, I explore people's motivations in choosing or refraining from seeking different kinds of alternative modalities in relation to affliction and healing. The purpose of this project is to answer the question, what factors affect 
people's decision of seeking or refraining from pursuing spiritual and alternative practices in contemporary Cairo?

$\cdots$

I answer the question and analyze these critiques using a multi-sited interpretive reflexive ethnography that was conducted by carrying out participant observation in five wellness places, two from-home practitioners, and five online applications. The interlocutors and interviewees are spiritual healing practitioners and wellness places' owners. In Egypt, there is a widespread lack of social acceptance that is rooted in financial, religious, and scientific preferences. Locally, this lack of acceptance is also supported by the government, which exerts effort to cancel the existence of unorthodox practices. Globally, there is also a lack of acceptance that is rooted in not only economic and scientific reasons but also cultural ones such as cultural and spiritual appropriation. This piece advocates for having a more holistic approach to wellbeing in conversations about affliction and healing.

The study contains a very good list of references, with about 350 academic reference items. Apparently, many well-known authors are shown on it, including Michel Foucault, Gilles Deleuze, Pierre Bourdieu, Anthony Giddens, Susan Greenwood, Arthur Kleinman, Claude Lévi-Strauss, to name just a few. And one author in the references is from our ISR SDAG Lab, Quan-Hoang Vuong.

In Table 1, we count the reference items for authors with at least three works cited in the study, except the indispensable name Gilles Deleuze. We reason that if an author is referenced three times in a work, the citations must carry with them the significance of the work and hence the corresponding author. (But since Deleuze's significance is given, we include the statistics in the table, albeit the actual count is 2.)

Table 1. Authors with at least three references (except Deleuze)

\begin{tabular}{|l|l|l|}
\hline Cited authors & $\begin{array}{l}\text { Number of } \\
\text { reference } \\
\text { items }\end{array}$ & Type \\
\hline Gilles Deleuze & 2 & Book \\
\hline Omnia El Shakry & 3 & Article / book \\
\hline Michel Foucault & 11 & Book / book chapter \\
\hline Paul Heelas & 3 & Book / book chapter \\
\hline Claude Levi-Strauss & 3 & Book / book chapter \\
\hline Quan-Hoang Vuong & 4 & $\begin{array}{l}\text { Article / chapter / encyclopedia entry / working } \\
\text { paper }\end{array}$ \\
\hline
\end{tabular}


The "type" column shows different types of work cited, be it a journal article, book, book chapter or else.

Now, let's look at the results.

Unsurprisingly, Foucault is the most frequently cited author, top the list with 11 items. And his magnum opus [5] appears on the list, for sure. Google statistics show that this work alone has received nearly 90 thousand citations from all walks of life. This number is undoubtedly huge by whatever standards. His other work is also a highly cited book, Security, Territory, Population [6].

Deleuze's magnum opus also appears [7]. This work has already attracted more than 40 thousand citations. His other work on the list is Negotiations [8], which has been cited more than 4000 times thus far.

Concerning another famous author, Levi-Strauss, both of his best-known books appear on the references [9-10]. Both works have received well above 10 thousand citations each.

Now, the other three are "younger" and active authors. Two are Westerners, and the only non-Western is a Vietnamese with his theory on mindsponge processes [11-12] and cultural additivity [13].

Influential intellectuals like Foucault, Deleuze or Levi-Strauss have influenced generations of thinkers and writers. Thus, it is no surprise that their works are the foundation of El Fakahany's exploration in finding "people's motivations in choosing or refraining from seeking different kinds of alternative modalities in relation to affliction and healing." Meanwhile, Omnia El Shakry and Paul Heelas are two leading experts in their respective fields. El Shakry has written extensively about the intellectual and cultural cultural history Middle East, especially religious sciences in Egypt [14-16]. Heelas is a sociologist and anthropologist who has contributed to the study of spirituality and modernity [17-19].

The classic works of Foucault or Deleuze, and the relatively modern contributions of El Shakry and Heelas are representatives of the default Western-centric mode of knowledge. These authors are from the West, trained in the West, and project an understanding of the world through the lens of Western ideologies. Therefore, it is important to see the theoretical contribution of a non-Westerner in El Fakahany's paper. It helps to balance the author's discussion with ideas from different parts of the world.

\section{References}


[1] Nguyen, T. T. H., Nguyen, M. H., \& Ho, M. T. (2021). Crossing the 100-publication milestone to celebrate the new year 2021. OSF Preprints; doi:10.31219/osf.io/tyqj5.

[2] Vuong, Q. H. (2018). The (ir)rational consideration of the cost of science in transition economies. Nature Human Behaviour, 2(1), 5.

[3] Vuong, Q. H. (2019). Breaking barriers in publishing demands a proactive attitude. Nature Human Behaviour, 3(10), 1034.

[4] El Fakahany, S. (2021). Meanings of Mindfulness and Spiritual Awakening: Affliction and Holistic Healing in Contemporary Cairo. The American University in Cairo MA Dissertation (May 25). Retrieved from: https://fount.aucegypt.edu/etds/1627/

[5] Foucault, M. (2007). Discipline and Punish: The Birth of the Prison. Duke University Press.

[6] Foucault, M. (1978). Security, Territory, Population. Lectures at the Collège de France. St Martin's Press.

[7] Deleuze, G., \& Guattari, F. (1988). A Thousand Plateaus: Capitalism and Schizophrenia. Bloomsbury Publishing.

[8] Deleuze, G. (1995). Negotiations, 1972-1990. Columbia University Press.

[9] Lévi-Strauss, C. (2008). Structural Anthropology. Basic books.

[10] Lévi-Strauss, C. (1962). Savage Mind. Chicago, IL: University of Chicago.

[11] Vuong, Q. H., \& Napier, N. K. (2015). Acculturation and global mindsponge: an emerging market perspective. International Journal of Intercultural Relations, 49, 354-367.

[12] Vuong, Q. H. (2016). Global mindset as the integration of emerging socio-cultural values through mindsponge processes: A transition economy perspective. In J. Kuada (ed.) Global Mindsets: Exploration and Perspectives (pp. 109-126). London: Routledge.

[13] Vuong, Q. H., et al. (2018). Cultural additivity: behavioural insights from the interaction of Confucianism, Buddhism and Taoism in folktales. Palgrave Communications, 4(1), 143. 
[14] El Shakry, O. (2007). The Great Social Laboratory: Subjects of Knowledge in Colonial and Postcolonial Egypt. Stanford University Press.

[15] El Shakry, O. (2011). Youth As Peril and Promise: The Emergence of Adolescent Psychology in Postwar Egypt. International Journal of Middle East Studies, 43(4), $591-610$

[16] El Shakry, O. (2017). The Arabic Freud: Psychoanalysis and Islam in Modern Egypt. Princeton University Press

[17] Heelas, P., and Woodhead, L. (2005). The Spiritual Revolution: Why Religion Is Giving Way to Spirituality. Oxford: Wiley-Blackwell.

[18] Heelas, P. (1996). The New Age Movement: The Celebration of the Self and the Sacralization of Modernity. Oxford: Blackwell.

[19] Heelas, P. (2009). Spiritualities of Life: New Age Romanticism and Consumptive Capitalism. Oxford: Blackwell. 